\title{
Making Sense of the European Union: Mapping 'Thought Communities' in Six EU Member States ${ }^{1}$
}

\author{
Jozef Bátora ${ }^{2}-$ Pavol Baboš ${ }^{3}$ \\ Department of Political Science, Faculty of Arts, Comenius University, \\ Bratislava \\ IR Department, Webster Vienna Private University, Vienna
}

\begin{abstract}
Making Sense of the European Union: Mapping 'Thought Communities' in Six EU Member States. How do Europeans make sense of the European Union (EU) and its processes of integration? Are there patterns of such understanding shared by citizens across borders of EU member states? The current article uses relational class analysis (RCA) to establish whether there are groups of citizens in selected EU member states sharing ideational construals of the EU. The purpose here is to complement extant studies of public attitudes towards the EU by exploring how citizens actually make sense of the Union. we develop an analytical framework and apply it to analyze survey data from a representative sample of citizens from six EU member states - Finland, France, Germany, Hungary, Italy and Slovakia $(\mathrm{N}=4249)$.

Sociológia 2020, Vol. 52 (No. 6: 527-558)

https://doi.org/10.31577/sociologia.2020.52.6.22
\end{abstract}

Key words: Sense making; relational class analysis; construals; publics; European Union

\section{Introduction}

How do Europeans make sense of the European Union (EU) and its processes of integration? How do ordinary citizens understand the EU as a political entity and as a political order? Are there patterns of such understanding shared by citizens across borders of EU member states? The current article uses relational class analysis (RCA) to establish whether there are groups of citizens in selected EU member states sharing ideational construals of the EU. The purpose here is to complement extant studies of public attitudes towards the EU by exploring how citizens actually make sense of the Union. This might seem trivial but, upon closer inspection, it seems useful to address the dimension of cognition and sense-making when we study public opinion on the EU. Put simply, while two Europeans may approve of or oppose a particular

\footnotetext{
${ }^{1}$ Work on this article was supported by the Slovak Research and Development Agency (grant no. APVV 15-0732) and by the EU3D project supported by the Horizon2020 program (Grant Agreement No. 822419). We are grateful to Amir Goldberg for his cooperation in developing the questionnaire design and performing relational class analysis on the data set. Useful comments and suggestions on earlier versions of the article were provided by Laszlo Bruszt, Branislav Dolný, John E. Fossum, John Gould, Zsolt Gál, Tim Haughton, Marta Králiková, Erik Láštic, Darina Malová, Matúš Mišík, Matej Navrátil, Johannes Pollak, Samuel Schubert, Milada Vachudova, Aneta Világi as well as by the two anonymous reviewers.

2 Address: Prof. Jozef Bátora, MPhil. PhD., Department of Political Science, Faculty of Arts, Comenius University, Gondova 2, 81102 Bratislava 1, Slovak Republic; IR Department, Webster Vienna Private University, Praterstrasse 23, 1020 Vienna, Austria; E-mail: batora3@uniba.sk

3 Address: Mgr. Pavol Baboš, MSc., PhD., Department of Political Science, Faculty of Arts, Comenius University, Gondova 2, 81102 Bratislava 1, Slovak Republic. E-mail: pavol.babos@uniba.sk
} 
aspect of the Union's policy, they may not see and comprehend the Union in the same way. The EU is namely notoriously difficult to categorize and remains, as Jacques Delors famously put it, an 'unidentified political object' (Delors 1985). While it is often compared to sovereign states and international organizations, it fits neither the former nor the latter category. It is an ambiguous political entity and an unsettled political order in constant development (Bartolini 2005; Olsen 2010). As such, it needs to be made sense of by international partners it interacts with as well as by its own citizens. It is in such processes of sensemaking that social and political structures attain their social existence and a degree of social stability (Weick 1995, 2001). Indeed, if we try to understand how people form their preferences and how they interpret political phenomena, it is useful to first get an analytical grip on the processes of how they make sense of their political order and the phenomena present in it (Weick 1995: 14). This is particularly important in unsettled or emerging political orders such as the EU.

We suggest that a useful approach to studying sensemaking in the EU is using 'relational class analysis' (RCA) to map out 'thought communities' (see Goldberg 2011) - meaning communities of citizens sharing understandings, schemas or construals of the EU - found across national boundaries in EU member states. To do this, we develop an analytical framework and apply it to analyze survey data from a representative sample of citizens from six EU member states - Finland, France, Germany, Hungary, Italy and Slovakia $\left(\mathrm{N}=4249^{4}\right)$. There are two main sets of findings. First, we show that there are several identifiable thought communities in each of the surveyed member states. More importantly, though, these communities are transnational as there are identifiable thought community similarities across a number of member states. This indicates that there exist transnational cognitive foundations of the EU as a political order in and across European societies. Second, we show that there are no identifiable socio-demographic predictors of citizens' belonging to 'thought communities'. In other words, there seems to be no systematic correlation between socio-demographic conditions of citizens and their understanding of the EU. This, we argue, provides a complimentary perspective to studies of the public perceptions of the EU identifying various predictors of EU citizens' approval of the EU and its various policies (e.g. Medrano 2003; Hooghe - Marks 2005, 2009; McLaren 2006; Hooghe et al 2007). Also, the current study complements findings of studies of trans-border interactions as conditions of European identity formation in individual citizens (Deutsch 1957; Mau 2007; Fliegstein 2008; Kuhn 2011, 2015). These studies show that individual citizens' involvement in transnational and/or cross-border

\footnotetext{
${ }^{4}$ The target sample size was set to 1,000 per country.
} 
interactions is correlated with higher likelihood of these citizens embracing identities as Europeans and other forms of cosmopolitan European selfidentification. We argue here that it is not a given that citizens embracing these types of identities as Europeans would actually share the same understanding of what it means to be a European, i.e. it is not clear what kind of EU they would have an identitarian attachment to. Hence, when analyzing citizens' attitudes towards the EU and its integration processes - i.e. their positions towards these - it is also useful to find out how these respondents actually conceptualize the EU and its integration processes - i.e. how they make sense of it. Our data indicate that processes of sense-making in relation to the EU are not systematically correlated with socio-demographic factors. In this, we do not contradict Mau (2007) or Kuhn $(2011,2012,2015)$ who found correlations between socio-demographic variables such as levels of education, income and frequency of travel, and the degree of European identity in individual citizens. Our findings merely underline that, first, there may be different iterations of 'European identity' based on how citizens make sense of the EU and, second, sense-making in relation to the EU seems not to depend on citizens' involvement in transnational interactions. Put simply, while two people may identify as 'European', it is not a given that it is the same notion of 'Europe' they entertain. As our findings suggest, irrespective of education level or experience with travel, people may work with different cognitive systems of reference activating different construals when they think of the EU. Finally, the current article also shows that standard concepts used in explaining the EU in academic analyses and/or elite political discourses are not necessarily used by the broad strata of citizens when they perceive, experience and make sense of the EU. Thus, based on our findings, we suggest it is useful to focus more analytical attention to studying the EU from a 'bottom-up' perspective, i.e. exploring how ordinary citizens think of the Union as a social and political phenomenon present in their daily lives.

The current approach provides a number of innovations with a potential of generalizable application beyond the case of the EU. First, public attitudes towards governments and political entities have been studied in terms of identifying citizens' positions - i.e. actors' normative beliefs (DiMaggio Goldberg 2018). Less attention has been paid to the study of actors' construals, i.e. meaning structures upon which actors build to understand social domains (ibid.). The current approach focuses on the latter and shows how construals can be studied in political contexts. Second, actors' attitudes towards social and political phenomena have been traditionally studied in individual national contexts. The current approach demonstrates that it is, in fact, possible and useful to study construals comparatively in various national settings. Third, while this approach has been applied to study shifts in music taste (Goldberg 
2011), political preferences and voter behavior (Baldassarri - Goldberg 2014), and in cultural structures related to populist and extremist political preferences (Daenekindt et al 2017), it has not been used in studying processes of sensemaking in relation to emerging political entities such as the EU. We show that RCA-based analyses of 'thought communities' can be useful in studying public attitudes towards unrecognized states and other types of emergent political entities that do not fit established categories (e.g. Kosovo, Kurdistan, ISIS). Finally, RCA-based studies to date used publically available data-sets such as General Social Survey (see Goldberg 2011). For the purposes of the current analysis we designed our own survey with 25 questions aimed specifically at collecting data to be used for the purposes of RCA of thought communities in the EU. The current study hence provides also methodological lessons for designing surveys for RCA-based studies.

The paper proceeds as follows. The first section addresses the conceptual challenge of making sense of the EU. The second section discusses the concepts of sensemaking and thought communities and introduces some of the key features of RCA as a methodological approach for studying these. Building on this, the third section develops the analytical framework for analyzing thought communities in the EU. The fourth section then applies the framework to present findings from a survey from six selected EU member states. Conclusions follow.

\section{The challenge of making sense of the $\mathrm{EU}$ and its integration processes}

In 1985, the then European Commission President, Jacques Delors asked his fellow Europeans to consider that

"in 30 or 40 years Europe will constitute a UPO - a sort of unidentified political object - unless we weld it into an entity enabling each of our countries to benefit from the European dimension and to prosper internally as well as hold its own externally“" (Delors 1985, italics added).

Arguably, more than 30 years later, this characterization still holds. The EU remains an unsettled order with ambiguous characteristics (Olsen 2010; Fossum 2005; Bátora - Fossum 2020). As a political order and political entity, the EU represents a multiple set of challenges to key categories of modern political organization including notions of sovereignty, national interests and roles of member states (Puchala 1972; Ruggie 1993; Krasner 1999; Hix 2004; Bátora - Hynek 2014). Given the complexities of the EU's institutional makeup, it is not all that surprising that citizens have a hard time understanding the highly complex policy making processes in the EU's institutions. Partly, this results in euroskeptic tendencies even in countries with traditionally high levels of EU approval in Eurobarometer surveys (Baboš - Világi 2017). But, more 
generally, it is not a given that average EU citizens are clear about the nature of the EU as a political order and a political system producing rules and regulations with direct impacts on daily lives of citizens. Indeed, as the processes leading to the Brexit referendum have shown, citizens in EU member states have difficulties interpreting EU policy making processes and they easily succumb to various myths (Fossum - Graver 2018). Hence, if we seek to get an analytical grip on the public perceptions of the EU, it may be necessary to complement data on approval rates for the $\mathrm{EU}$ and its various policies with data on how do citizens think of the EU, how they understand it and how they make sense of it. The next section explains why it is necessary to study sensemaking prior to or in combination with interpretations of social and political phenomena.

\section{Sensemaking and thought communities}

The analytical point of departure in the current analysis is the notion that in social action sensemaking precedes interpretation (Weick 1995: 14). If an actor is to interpret what a political initiative or a political action means, s/he first needs to make sense of the situation, of the events unfolding and of her/his appropriate role in that situation (March - Olsen 1989: 23). As Weick (1995: 14) clarifies,

"The act of interpreting implies that something is there, a text in the world, waiting to be discovered or approximated. ... Sensemaking, however, is less about discovery than it is about invention. ... To engage in sensemaking is to construct, filter, frame, create facticity ... and render the subjective into something more tangible. ... Thus, the concept of sensemaking is valuable because it highlights the invention that precedes interpretation."

Processes of sensemaking are institutionalized and structured by culture as a system of inter-subjectively shared representations (Schutz 1944). When a person is thinking, it involves not only an individual neuro-cognitive process but also an impersonal collectively constructed dimension - a socially constructed set of notions structuring our thinking (Zerubavel 1997). It is due to such shared socially constructed notions that we can think of historical events that happened several centuries ago and we have not experienced them ourselves. Also, it is due to such conceptual structures that we can think of artworks as "primitive" or "postimpressionist" - social constructs provide us with categories that help us order reality (ibid.: 7). Making sense of the world and the events around us is hence a deeply socially embedded process. Also, as we will show below it make sense to study constructs using RCA in national contexts. 
This has implications for epistemology when we seek to get a grip on social phenomena such as identity formation. As Zerubavel (1997: 9) points out, between the purely subjective inner world of the individual and the absolutely objective 'physical' world out there, there is a mediating layer of an intersubjective world that is quite distinctive from them both (see Berger Luckmann 1967; Searle 1995). Culture as a set of socially constructed and inter-subjectively shared notions enabling us to grasp the physical world and social phenomena is not exogenous to individuals but it is both individuated and socially distributed (Goldberg 2011: 1400). Shared representations and related expectations provide routinized meanings to situations and objects in our environment. They activate what may be termed schemas or construals institutionalized and collectively shared links between situations and objects that we encounter (ibid., see also Schutz 1944 on the process of 'typification', Zerubavel 1997). Construals enable routinized categorization of observed events, characteristics, people and actions. Such delineate the frames of particular domains in society, their boundaries and the usual practices and reactions within such domains. Individuals may have different political leanings (e.g. social democrat or conservative), but they share a basic understanding of a system of political parties divided by particular cleavages that channel political interests. Hence, for instance, to analyze shifts in the institutionalized order of political preference formation, it is not sufficient to explore the degree to which people support conservatives, liberals or social democrats - these kinds of preferences underlie changes and each party affiliation may be more or less strong at different periods of time due to varying political circumstances. Yet that tells us relatively little when it comes to shifts in the very constellation of shared representations - the institutionalized construals producing meanings that influence how people organize their political preferences (Baldassarri - Goldberg 2014). As Goldberg (2011: 1402) clarifies "To have a shared understanding, therefore, does not imply having identical attitudes or behaviors; rather, it suggests being in agreement on the structures of relevance and opposition that make actions and symbols meaningful." To analyze existing construals, it is necessary to capture individuals' views on a whole range of aspects pertaining to a particular domain and identify what construals are active in which segments of a particular society.

It is also useful here to differentiate between construals and positions. Construals are defined as the structures of relevance and opposition, i.e. meaning structures upon which actors draw upon when making sense of domains of social life (DiMaggio - Goldberg 2018: 2). Positions, in turn, are actors' normative beliefs given the construals they adopt (ibid.). Once an actors makes sense of a situation or of a domain of social life, i.e. adopts a construal, 
it is in a position to adopt a meaningful position on events and developments relevant to that particular domain. In Weick's terms, while sensemaking requires the ability to adopt a construal relevant to a domain, adopting a position is what then ensues as an actor seeks to interpret events within that domain. Of importance in the context of the current analysis is the notion that actors with the same construal may, in fact, adopt widely diverging positions within the same domain.

A group of actors sharing a particular construal would be termed a thought community (Goldberg 2011; see also Mannheim 1954). They think about a particular social domain in a particular way. They do share the same structure of relevance and opposition that defines the domain.

A useful methodological approach to identifying and mapping 'thought communities' is relational class analysis (RCA). This builds on the concept of relationality, i.e. "the extent to which two individuals exhibit a similar pattern of association between measures of opinion on issues that constitute a particular social domain" (Goldberg 2011: 1399). Using RCA allows us to identify groups of individuals characterized by similar patterns of responses in multivariate data sets (for application see also Baldassarri - Goldberg 2014).

The next section builds on these ideas and elaborates on our analytical framework for mapping thought communities among citizens in the EU.

\section{Mapping thought communities in the EU: An analytical framework}

\section{Europeanness as a predictor in thought community formation}

As it is beyond the scope of this section to cover the literature studying public attitudes towards the EU, we will limit ourselves to locating our approach in relation to the key dimensions in the body of research ${ }^{5}$. Public attitudes towards the EU as a political project have been studied in relation to three key dimensions. First, attitudes were shown to vary in relation to various aspects of the EU as a political order, e.g. political community, regime processes, regime institutions, regime principles and political authorities (Norris 1999; see also Boomgaarden et al 2011). Second, there is a body of research underlining variation across nations and focus on national structural features as key predictors of attitudes. As Hooghe and Marks argue in their seminal study, "political parties and countries are irreducible political contexts that interact with individual attributes to produce political effects - in this case, support for or opposition to European integration. To the extent that individuals are clustered in parties and countries, they should not be regarded as independent units of analysis" (Hooghe - Marks 2005: 427). Their findings then generalize

\footnotetext{
${ }^{5}$ For a comprehensive overview of the literature on public attitudes towards the EU, see Loveless and Rohrschneider (2011) and Kuhn (2015).
} 
perceptions of the EU along the national lines identifying cleavages between, for instance, net receivers of EU subsidies (e.g. Greece, Portugal, Spain and Ireland) and net donors (e.g. Scandinavian EU members) with the publics of the former considerably more EU-supportive than the publics of the latter. Also, factors such as national histories, national patterns of statehood formation and national welfare systems are found to correlate significantly with degrees of support for the EU (Hooghe - Marks 2005; see also Medrano 2003). In these approaches, structural features of national contexts are seen as predictors of citizens' attitudes. National communities then are also the primary instruments for clustering respondents.

Yet, such country based approaches implicitly treat national societies as single and rather homogeneous group of citizens with similar understanding of the EU. These approaches neglect the possibility of individual experiences of European integration and, by extension, of the EU as a political order. Here, Fliegstein's (2008) transactional approach focusing on individual transboundary practices of Europeanness seems more useful. As Fligstein (2008: 124-127) points out, European identity formation may be better understood if we focus on actors involved in cross-societal interactions in various fields in which European integration happens on a daily basis (e.g. economic, social or political fields). He argues it is useful to differentiate between actors involved in such interactions and those not involved or involved only to a limited extent. The former group - or those he terms Europeans would include people who have the opportunity to travel to other European countries, learn and speak other languages and interact with other Europeans. This would include the economic beneficiaries of integration such as business owners, managers, academics and various white-collar experts. Young people and educated people would also be more likely to have experience from interactions with other Europeans and/or from having lived in another EU member state. Finally, people with higher income would be more likely to be involved in travel and other kinds of interactions with societies in the EU member states. Contrary to the 'Europeans', there is a broadly conceived group of those who lack opportunities and means for involvement in interactions with societies of other EU member states. This would include blue collar workers, less affluent people, people with lower levels of education and lower levels of income (ibid.: 126-127).

For the purposes of the current analysis, we developed three indicators of person being Europeanized ${ }^{6}$. In the survey, we asked people how many foreign languages do they speak, how often do they travel to another EU country, and

\footnotetext{
${ }^{6}$ By the term europeanization, we do not mean sharing in a particular European identity or particular form of identification with Europe. We rather see this as expressing a degree of experience with trans-border interactions be that in terms of linguistic skills or in terms of experience of travel or living in another EU country.
} 
if they lived in another EU country. These indicators allow us to measure the degree of citizens' Europeanization, including non-Europeanized at all. As the mutual correlation of the indicators was rather low (confirmed by low level of Variance Inflation Factor), we decided to keep the three of them in the analysis separately, and not compute a single Europeanization index. Combining these would result into loss of information, which is particularly undesirable due to qualitative difference between individual indicators.

The way we treat those labels - 'Europeanized' and 'non-Europeanized' citizens - have no positive or negative connotations here. They merely express the quality of being more or less involved in various forms of cross-societal interaction in the EU context. In the current analysis, we test whether the indicators of 'Europeanization' of citizens correlate with particular 'thought communities' sharing construals of the EU.

In sum, the current analysis tests whether 'thought communities' span across borders of EU member states and whether these thought communities correlate with the degree of 'europeanization' of respondents. Despite the fact that this work is exploratory by design, we assume that thought communities may be transnationally distributed across borders of EU member states. Additionally, we assume the degree of Europeanization may be related to membership in specific thought communities.

Europeanness of citizens and dimensions of the EU's political order: Designing the survey

Patterns in the development of the EU's political order can be thought of along the lines of at least five dimensions. The first three speak to principles of political organization: hierarchy, market and network; the last two to basic public goods the EU provides: peace and welfare (see for example Offe 2003). When it comes to principles of political organization, literature on the EU suggests that there may be at least three leading paradigms of the EU's mechanisms of integration: EU as a market; EU as a hierarchy; EU as a network (Ansell 2000; Jessop 2004; Knill - Tosun 2009) ${ }^{7}$. In ideal-typical terms, this would entail particular and mutually different characteristics and logic associated with the paradigms. The paradigm of the EU as a market implies that the EU is merely a functional regime that works to support market exchanges between member states. The paradigm of the EU as a hierarchy would imply that the EU is a federation in the making. This would entail clear expectations in terms of the possibilities and limits of member states' actions which would fit with models of federal provinces in federal states. Finally, the schema of the EU as a network would also feature a set of characteristics

${ }^{7}$ These models build on organization theory paradigms of market, hierarchy and network (see Powell 1990). 
including sharing of resources, pooling, horizontal coordination and cooperation, a sense of mutual obligation. These three paradigms have also been used in the literature to explain the EU's external relations with countries in the EEA (Lavenex 2009) or associated countries in the EU's Eastern neighborhood (Lavenex - Schimmelfennig 2009, 2011).

When it comes to the basic public goods that the EU provides, welfare and peace stand out. While welfare states in the EU differ in their structures and founding philosophies (Esping-Andersen 1990), the social and welfare dimension has been a key aspect in the process of European integration (Scharpf 2002). This applies also on the level of public attitudes where, as Van Oorschot (2006) shows, European citizens share a common and fundamental deservingness culture meaning that elderly people, sick and disabled people are seen as deserving social protection and welfare benefits and this applies across countries and social categories of respondents. When it comes to peace, it has been seen as a characteristic feature of the EU's political order by functionalists and neo-functionalists (Mitrany 1943/1994; Haas 1964), social constructivist interactionists (Deutsch 1957) as well as liberal inter-governmentalists (Moravcsik 1998). The notion of the EU contributing to maintaining peace and security is also among the key characteristics of the EU as seen by the citizens (Parlemeter 2018: 23). Welfare and peace are also featured prominently in EU's official presentation of its purpose and its institutions ${ }^{8}$ as well as in speeches by some the EU's leading political figures such as Jean Claude Juncker or Emmanuel Macron (Macron 2018). In our research, peace and welfare hence are reflected among the dimensions along which we developed a set of questions helping us to identify respondents' construals of the EU.

The design of individual survey items was consequently based upon the fact that certain understanding of the EU translates into specific set of inter-related expectations. To grasp these, statements were phrased as normative preferences in terms of what could be expected from the EU, with respondents having to choose the degree of agreement.

\section{Selection of cases:}

The selection of six EU member states for the current study - Finland, France, Germany, Hungary, Italy and Slovakia - was informed by project aims in the EURECOR project focusing on publics in selected large and small EU member states. The selection of countries was also related to language skills of research team members. The sample thus includes three big and founding member states (FRA, GER, ITA) and three small and newer member states (FIN - member since 1995, HUN and SVK - members since 2004). Another variation in the

\footnotetext{
${ }^{8}$ See, for instance, the European Parliament's presentation of the EU's objectives at http://europarlamentti.info/en/valuesand-objectives/objectives/, accessed on April 23, 2018).
} 
sample is membership in the Eurozone as five countries are members and Hungary is not.

\section{Data Collection}

Data was collected by a professional contracted agency ${ }^{9}$ with experience in pan-European surveys and offices in all the member states studied. The survey was translated from English into the local languages (Finnish, French, German, Italian, Hungarian and Slovak). Translations were controlled by reverse translation testing provided by the agency and also by the authors of this paper. Surveys were then distributed electronically between December 2017 and January 2018. In each of the selected member states we collected a representative sample of 1000 respondents. The survey was administered online and stratified quota sampling was used to ensure representativeness of the sample in regard to gender, age, education, region and residence size.

Attitudes towards various aspects of European integration were measured on a 5-point Likert scale. Based on five theoretically driven principles of the EU's political order we developed 15 statements, three statements capturing each of the principle. Two of the questions were phrased in a way of confirming a given principle (e.g. hierarchy/EU federation) and one of them refuting it. This is to ensure that respondents paid attention and did not simply answered all items with a single answer (i.e. choosing the same option fifteen times in a row, mostly out of laziness; De Vaus 2014). Respondents were asked to rate their level of approval of a particular structural set up of governance institutions or principles (see Appendix 1 for full list of items).

Building on Fligstein's (2008) transactional perspective on europeanness, we included three indicators. These asked about (i) the number of years spent in another EU country, (ii) frequency of visits to other EU countries and (iii) language skills measured as number of languages a respondent speaks. These indicators speak to actual experience with social contexts of other EU societies / states and / or linguistic skills in accessing such contexts. Finally, we also asked about political affiliations ${ }^{10}$. One of the questions then addressed a general attitude towards the EU, i.e. whether the respondents evaluated the EU as a good thing. Standard demographic and socio-economic variables were included as well (age, gender, education at ISCED level, size of residence and income).

\footnotetext{
9 TNS-Kantar Slovakia.

${ }^{10}$ We could have included other indicators such as relatives in other EU member states or participation in European Parliament elections but our survey had a limited number of questions and we had to select those that we found represented the respondents' direct experience with other societal contexts in the EU.
} 
Relational Class Analysis

Relational Class Analysis was introduced by Goldberg to analyze the extent to which people "organize meaning in similar ways" (2011: 1403). Goldberg claims that the traditional social scientific methods that employ relational approach in studying people's attitudes focus either on similarities "between variables (e.g., multidimensional scaling, factor analysis) or between individuals (e.g., cluster analysis)" (2011: 1404). Goldberg's approach is designed to overcome this issue and is "sensitive to relational patterns both within and between observations" (ibid.).

For Goldberg, relationality is a key concept and it "measures whether the components of two vectors of the same set of variables follow a similar pattern." (ibid.) RCA, as Goldberg explains, works in three basic steps. It computes the relationality for each pair of respondents and create a graph representing all pair and connections between them. Insignificant connections are then removed, and RCA partitions the graph of whole population into subgroups "of schematically similar observations using a graph-partitioning algorithm" (2011: 1405). In our study we set the significance level at $\alpha=0.05$. This means that classification of respondents into thought communities is based on computational algorithm. For mathematical definition of relationality, including equations see Goldberg (2011). To read how RCA is different from similar multivariate methods for relational structure identification (i.e. factor analysis, latent class analysis, cluster analysis) see Appendix C of Goldberg (2011).

This approach should lead to thought communities that grasp exclusive 'construal' because it cluster people with same pattern of expectations towards the EU. So if there's a community A with a specific understanding of the EU leading to a specific expectations from the EU, only persons with aligned set of expectations is included in the thought community. On the other hand, it may well happen that there will be two people with opposed positions in the same thought community. This is because RCA clusters people according to a specific relationship among all 14 items, and not where a respondent is placed on a single item.

Relational Class Analysis assumes interval/ratio level of measurement. However, as it is rule of thumb in social science, 5-point Likert scale is an approximation of interval measurement. Basically the same scale (running from strongly dislike to strongly like) is used in Goldberg's seminal article (2011) as well as in others (Baldassari - Goldberg 2014; DiMaggio - Goldberg 2018). DiMaggio and Goldberg used also four-point scale, and Baldassari and Goldberg (2014) used even several items measured on three point scale. 
We included $14^{11}$ items representing five principles of EU's political order into RCA. To perform the analysis we used an R package called 'RCA' (Goldberg - Stein 2016). The analysis produces two main results, the vector of class membership and a matrix of relationality measure among tested items for each class. The relationality matrix can be then used to visualize classes in a form of network graphs or heatmaps.

As we argued above, and in line with the argument that national contexts are crucial for processes of sense-making (Zerubavel 1997), we performed the analysis on country-by-country basis ${ }^{12}$. There's additional reason we perform the analysis in six countries separately. The data collection process was designed to produce six representative samples of respective countries. The findings are thus representative of, and generalizable to a national state. Pooling the sample together would produce results that would in no way represent the EU as whole. Therefore we see no sense in performing the analysis on the pooled samples.

Before proceeding to analysis, we had to delete cases with missing data. This is a requirement of RCA that cannot handle missing data. This way the targeted sample size of 1000 decreased on average to 700 . We studied the subsample with missing data and found no pattern in that a particular item or set of items would seem extra problematic. We also ran logistic regression to see whether there are any statistical differences between subsamples with missing data on the one hand, and subsample with complete data on the other hand. Again, we found no pattern and thus concluded that the data are missing completely at random. Thus we opted for listwise case deletion as the most strict way of handling the missing data while not introducing bias to the analysis.

Having performed the analysis, we produced the heatmaps including the relationality measure in order to analyze mutual relationships within individual thought communities and countries. (see Appendix 2). The number of identified classes is a product of a partitioning algorithm and thus is not a deliberate choice of the authors (as opposed to factor analysis / latent class analysis). In other words, the decision on respondents' membership in a

\footnotetext{
11 One of the original items was omitted in the final analysis. The item reads: "EU should expand its social welfare protection for all EU citizens to protect us from global market forces." The reason for omitting this is that the inclusion of the item caused RCA to produce many single-membered classes and the item was in no relationship to any other items in most of the communities in most of the states. This lead us to opinion that the item was misunderstood by a considerable share of respondents, as it asks about EU's welfare, comparing to market competition, low taxes and similar neo-liberal concepts. Therefore we concluded that omission of this variable would be the best way to proceed with the analysis without biasing the findings.

12 As a form of quality control we performed also the RCA on the whole dataset. The analysis produced the same results in the whole dataset, as in separate national analyses. Using the whole dataset we identified three thought communities with the same relationship structures within the communities.
} 
particular thought community (and thus the size of communities in each country) is the result of partitioning algorithm and not the researchers' choice. Based on particular values of relationality for each thought community we identified construals present in each of the member states. This was done in an inductive fashion. We studied each thought community separately, looking for patterns in the data and identified common, shared meaning connecting items with high values of relationality. Thus, the labels and interpretation of the emerged thought communities is the product of the authors and not the RCA package. What we then do in analyzing the results follows two steps. First, we examine the mutual relationship between the items and identify items that express high degrees of relationality. This is usually at the significance level $\alpha=0.05$ or above. Second, we study the patterns and ascribe a label (i.e. ideologues, pragmatists or communitarians) to a thought community characterized by a certain pattern of relationality. The patterns of relationality are identified by the algorithm in the RCA software and we then use our background as political scientists studying the EU to identify appropriate labels for relationality patterns identified by the software. Of course, we are aware of the constructivist approach that we hence apply. We also note, however, that this constructivism operates merely at the level of interpretation of the relationality patterns while these patterns as such were identified independently of our own input. Hence, ascribing labels and categories to thought communities are not mere impressions but theoretically informed processes of labelling of relationality patterns identified by the RCA software.

In a final step we performed six models of multinomial logistic regression, one for each country, to test our assumption that the level of citizens' Europeanization determines their belonging to a specific thought community. In addition to three Europeanization indicators we included the rest demographic and socio-economic variables as controls (Appendix 3). Sampling weights were used.

\section{Findings}

Before moving on to the presentation of findings, one important methodological caveat is in order. We do not seek to essentialize the data. We do not claim that the thought communities we identified are permanent or inherent to the societies under study. We also do not claim that the identified thinking styles, although present in several member states, are equally strong in all countries. Our findings necessarily speak to thought communities that could be identified during the period when the survey was distributed. If the same analysis would be performed at a different time following the same steps, one could arrive at different results. With that in mind, we can now report on our findings. 
We found three identifiable thought communities - subsets of respondents characterized by distinctive patterns of association among attitude items present among the populations of the six member states studied here. We labeled the thought communities according to the items that the thought community members share, i.e. based on the distinctive pattern. Each label is an analytical construct serving as a heuristic device enabling us to distinguish between clusters of respondents sharing patterns of association among attitude items.

Three communities we identified are labelled as follows: Ideologues, Pragmatists and Communitarians. What all three communities have in common is that they can clearly distinguish two levels of governance: national versus European one. Whether ideologues, pragmatists or communitarians, members of all communities seem to perceive this distinction as a relevant one (except for Finnish communitarians). What varies across communities is the layer of meaning that comes in addition to the shared recognition of two levels of governance. We elaborate on this additional layer in the sections describing the individual thought communities below.

Appendix 4 shows network diagrams for all countries and all communities. These diagrams are a visual aid to show similarities and differences among communities transnationally. In the diagram, nods represent the items in survey questionnaire, lines are representations of correlation among the items with the line thickness reflecting the strength of the corresponding correlation. Correlations below 0.3 (in absolute values) are omitted from diagrams.

\section{TC1: Ideologues}

The attitudes of people in this group are aligned and uniform for all 14 items. This means that people who tend to accept more EU interference in one area, for example security, tend also to accept it in others, and vice versa. Therefore, as a figure of speech, we could say this thought community expects all or nothing from the EU, This is empirically demonstrated in the way how respondents in this community answer systematically in one direction on all 14 items. Simply put, whether it comes to federalization, economic integration, democracy promotion or police cooperation, members of this community either want it all or reject it all. Arguably, this is a relatively simple and clear thinking style about the EU. Respondents in this community acknowledges the existence of the EU level of governance and its ability to provide outputs (just as any political system does). Subsequently, people either accept the EU level of governance and require the EU to deliver or they reject the EU's governance altogether and reject also the EU's outputs. Either way, they are consistent in the one-sided bias in their thinking about the EU. Given this one-sided 
approach to the thinking about the EU and its political system, we refer to this community as 'ideologues'.

The first column in Appendix 4 shows the TC1 diagrams (community of ideologues). Here, all 14 items are connected in a rather intensive way, although not necessarily every single node with all others. This reflects that respondents in this TC think systematically about all the surveyed items. Hence the correlations of all their answers.

\section{TC2: Pragmatists}

When respondents in TC2 think about the EU they think of two levels of governance as well as the outputs that a political system provides. However, for people in this thought community the governance level and policy outputs are two mutually independent lines of thinking, meaning that respondents' degree of acceptance of the EU's level of governance is not directly related to the extent they expect the EU-level to deliver outputs.

In other words, respondents in this group recognize the difference between the two levels of governance in the EU (national and EU-level). Yet, when it comes to outputs in areas such as security, peace or market economy, their preferred actor responsible for the delivery of outcomes does not necessarily correspond with their preferred level of governance.

Belonging to this group does not inform us about respondents' preferences in terms of who should provide for economic or security outputs. In principle, members of TC2 may appreciate that there are EU-level governance institutions but they do not necessarily expect this governance level to provide outputs - those could just as well be provided by national government institutions. This is the main reason we label this group pragmatists. This thought community is present in four countries: Finland, Hungary, Italy, and Slovakia (see Table 1).

The second column of Appendix 4 shows the TC2 diagrams (pragmatists, where applicable). There is a distinctive feature of four diagrams in the second column that, on the one hand, separates them from the diagrams in the first column, and, on the other hand, makes them similar. The same set of four nods (coop1, dem2, fed2, and peace2) are interconnected in a more dense way than the rest of the items, and they are only weakly linked to the rest (or not linked at all in Slovakia). These four nods/items are indicators of the political decision-making level and are similarly connected in all countries in TC1, TC2, and TC3. This is why we argue that the joint characteristic feature connecting all three thought communities is the recognition of two-levels of governance in the EU, i.e. the national- and the EU-level. What differentiates the various TCs is how the position on the governance levels is related to the rest of the items in the survey and also what actually represents 'the rest' of the items in each TC. 
In TC1, the thinking on the level of governance is tightly interconnected with the rest, i.e. the thinking on every single item in the survey is coherent across the board. In TC2, respondents relatively clearly divide their thinking on the level of governance and their thinking on the rest of the items. Here, the key is that 'the rest' in TC2 means more or less all the other items in the questionnaire including various policy areas such as police cooperation, federal political institutions, taxes and market competition, freedom of movement, digital services, etc. Therefore, we refer to it as policy outputs provided by a political system or, in short, system outputs. Network diagrams show that TC2 members' positions on the level of governance are not systematically linked with to the system outputs.

\section{TC3: Communitarians}

As members of $\mathrm{TC} 1$ and $\mathrm{TC} 2$, respondents belonging to TC3 can clearly distinguish between two levels of governance in the EU. However, they do not think systematically about the rest of the surveyed items, i.e. they do not seem to distinguish between political structures and policy outputs. Therefore, we argue, members of TC3 do not perceive the EU as the political system but rather as a political community or polity based on founding principles such as peace, cooperation, and political integration.

An important attribute of this community is that their preferred level of governance (national or EU-level) is not systematically linked with the positions on the issues of peace, police cooperation or market integration. Hypothetically, two persons in this community may be strictly in favor of national level of governance, yet one of them would prefer EU not to have federal ministries and a common army, while the other one would agree the EU should have those institutions. The distinction between TC 3 and TC1 is that in TC1 respondents' preferences towards the level of governance is strictly interdependent with their preferences on federal institutions such as federal army and federal governmental ministries. This is not the case in TC3 where we could not establish any such interdependence. When we compare TC2 and TC3, what they have in common is that they both acknowledge there are two levels of governance, and then in addition to that they think independently about a set of preferences. While this "set of preferences" in TC2 is represented by almost all system outputs in our survey, in TC3 it is just a selection of policy outputs (free movement of goods and services, democracy and peace) or political institutions (directly elected president, federal ministries or army) without a clear pattern. This indicates that TC3 members think about the EU as a community providing certain integration benefits and operating on a set of shared principles but without necessarily thinking about the structural arrangements that would be required for the delivery of such integration 
benefits and shared principles of cooperation. We found TC3 in all six countries. Again, being a member of this sub-community does not automatically mean that respondents support one of the governance levels (national or EU) or any of the specific policy outputs. These respondents are rather thinking about integration as a principle of cooperation and the public goods such as peace that it provides. But they do not link such cooperation with any levels of governance in any systematic way. Moreover, except for the levels of governance members of TC3 do not think about any other items systematically.

Of the three thought communities, TC3 is the least clearly crystallized one as the patterns of association of items in this community are weakly correlated when compared to TC1 and TC2. The fourth column in Appendix 4 shows network diagrams for TC3. Table 1 provides an overview of the three thought communities and their size in the six member states under study.

Table 1: Thought Communities in six EU member states (in \%)

\begin{tabular}{lccc}
\hline Country / Community & $\begin{array}{c}\text { TC1: } \\
\text { Ideologues }\end{array}$ & $\begin{array}{c}\text { TC2: } \\
\text { Pragmatists }\end{array}$ & $\begin{array}{c}\text { TC3: } \\
\text { Communitarians }\end{array}$ \\
\hline Finland & 40,50 & 23,52 & 35,98 \\
France & 42,67 & 0,00 & 56,33 \\
Germany & 40,42 & 0,00 & 59,58 \\
Hungary & 34,02 & 20,11 & 45,87 \\
Italy & 19,42 & 16,67 & 63,91 \\
Slovakia & 21,54 & 24,70 & 53,77 \\
\hline
\end{tabular}

Source: Authors

As noted in the description above, thought community membership alone does not reveal whether a respondent positively approves of the EU or not. Take for example TC1 - Ideologues: being a member of this TC does not mean the respondent is either in favor of the EU having federal political institutions or pushing for freedom of movement across borders. What we know with regards to TC1 is that these respondents share a rather simple construal of the EU as either something overly positive or something overly negative. Because of this, the members of TC1 are systematically in favor of or opposed to EUlevel policies in all the connected issue areas.

Table 2 summarizes the key characteristics of thinking styles about the EU in the selected communities. This summary provides brief overview of what the selected TCs have in common, as well as what is the main distinguishing feature in their thinking style. 
Table 2: Summary of key features of thought communities

\begin{tabular}{|c|c|c|c|}
\hline & $\begin{array}{c}\text { TC1: } \\
\text { Ideologues }\end{array}$ & $\begin{array}{c}\text { TC2: } \\
\text { Pragmatists }\end{array}$ & $\begin{array}{c}\text { TC3: } \\
\text { Communitarians }\end{array}$ \\
\hline $\begin{array}{l}\text { Signs of } \\
\text { acknowledgment of two } \\
\text { governance levels }\end{array}$ & YES & YES & YES \\
\hline $\begin{array}{l}\text { Signs of } \\
\text { acknowledgment of two } \\
\text { levels of policy outputs }\end{array}$ & YES & YES & $\mathrm{NO}$ \\
\hline $\begin{array}{l}\text { systematically aligned } \\
\text { attitudes towards } \\
\text { Levels of governance } \\
\text { and Levels of policy } \\
\text { outputs }\end{array}$ & YES & NO & N/A \\
\hline $\begin{array}{l}\text { Signs of } \\
\text { acknowledgment of } \\
\text { community/polity being } \\
\text { cornerstone or basic } \\
\text { organizing principle of } \\
\text { the EU }\end{array}$ & YES & NO & YES \\
\hline $\begin{array}{l}\text { systematically aligned } \\
\text { attitudes towards } \\
\text { Levels of governance } \\
\text { and Community } \\
\text { principles }\end{array}$ & YES & N/A & NO \\
\hline
\end{tabular}

Source: Authors

Do socio-demographic indicators serve as predictors of thought community membership?

In the next step, we explored whether there is any pattern connecting membership in thought communities with demographic, socio-economic and Europeanization factors among the respondents. We inspected data country by country via contingency tables and also ran separated multinomial logistic regression for each country. The main aim of logistic regression is to calculate the effects of covariates on the respondents' probability of membership in selected thought community. The logistic regression does so while simultaneously keeping the values of other variables constant. This is the reason why it provides much more precise estimates of the covariates' effect. The TC1 served as the basis for comparison. The results of the regression analyses are provided in Appendix 3.

Overall, we found no transnational, systematic pattern linking the independent variables to TC membership. On the contrary, there was rarely any influence identified. Gender was found to be important, with women having 1.813 times higher risk to be members of TC2 than men in Slovakia, and 1.730 times higher risk to be members of TC3 than men in Slovakia. Higher income 
contributes to 1.132 times higher risk of being in TC3 in Italy. Italians speaking more foreign languages have also lower risk of belonging to TC3 than TC1 (rrr=0.637). In Germany, respondents with higher education degree have 0.451 times higher relative risk of belonging to TC3 than respondents with low education. Physical age is also influential in terms that older people have lower risk of being members of TC3 (compared to TC1). Living in more rural areas also decreases the risk of being in $\mathrm{TC} 1$ in Hungary by about a quarter, compared either to TC2 or TC3. This means that the size of residence is only relevant for not being an ideologue, but does not tell us whether a person is more likely to be pragmatist or communitarian. On the other hand, having lived abroad is relatively strongly increasing the risk of being a pragmatist, the risk is about 2.5 times higher than being an ideologue. Travelling less also means increased risk of being member of TC2 in Finland. Table two summarizes presence/absence of the TC membership predictors in individual countries.

\section{Table 3: Summary of TC membership determinants}

\begin{tabular}{lll}
\hline & Pragmatists (v. Ideologues) & Communitarians (v. Ideologues) \\
\hline Slovakia & Gender & Gender \\
Hungary & Residence size, Living abroad & Residence size \\
Italy & Income & Foreign languages \\
France & No significant influence found & No significant influence found \\
Finland & Travel intensity & No significant influence found \\
Germany & No significant influence found & Age, Education \\
\hline
\end{tabular}

Source: Authors

Conclusion: The cognitive foundations of the EU's political order and the possibilities of generalization of the current approach

Results of various research on citizens' relationship to the EU are often used to show degrees of EU approval and attitudes towards its particular policies. Yet, given the EU's ambiguous and complex nature, it is not a given that all surveyed citizens actually share the same understanding of the Union. The current paper proposes a framework for analyzing thought communities in the EU using the method of relational class analysis (RCA). Applying the analytical framework on a representative data set we identified three distinct, transnational thought communities: TC1: Ideologues; TC2: Pragmatists; TC3: Communitarians.

Several of these thought communities were found to be present - in various sizes - in multiple member states (see Table 1). We could thus conclude that thought communities in the EU are transnational. 
When it comes to the question whether 'europeanization' in Fligstein's sense correlates with membership in particular thought communities, we found no clear evidence of such a correlation. While authors such as Mau (2007), Fligstein (2008) or Kuhn $(2011,2015)$ may be right that higher levels of europeanization of citizens (those scoring high on income levels, urbanization and cross-border interactions) may correlate with higher approval ratings for the EU, it is not a given that all those who approve of the EU share the same construals of the EU. Thus, two citizens may approve of the EU and the effects of its policy actions in a particular policy field but this could be $a$ ) a different kind of EU they approve of and $b$ ) they could be approving of the EU for different reasons. Also, we found no correlation between membership in particular thought communities and socio-demographic data. It appears that the EU is made sense of by respondents irrespective of socio-demographic indicators. This suggests that processes of sense-making and comprehension of ambiguous and difficult-to-categorize political phenomena present in the daily lives of citizens - such as EU integration - may be happening in shared group patterns with no or low correlation with factors such as levels of education, income or frequency of border transgression.

The article also provides a number of insights regarding the issue of how we should think of the publics in the EU. As our findings show, on the level of construals, national publics are not characterized by a single 'national' thought community, but by a specific constellation of thought communities present in a given national context. This is visible, for instance, in the small but still significant difference between Germany (or France) and Slovakia (or Finland), where the former does not feature TC2, while in the latter case TC2 represents almost a quarter of population. In somewhat simplified terms, Germany's and France's public sphere with its strongly represented 'communitarian' thought community (TC3) features different conditions for making sense of EU reforms than Slovakia or Finland with their relatively strongly represented thought community of 'pragmatists' conceptualizing the EU in terms of system outputs (TC2). This raises the question that would need to be tested by further research, namely how and to what extent a particular reform proposal publicly advocated by key proponents of EU reforms would resonate in different national settings given the variation in the presence of 'thought communities'. This has at least two kinds of practical policy implications.

First, differences in constellations of thought communities in different national settings could be one of the reasons why, for instance, French President Macron's proposals for EU reform bearing a strong federalist imprint focusing primarily on establishment of state-like governance structures on the EU-level might not automatically find resonance among citizens in Germany where almost $60 \%$ of citizens understand the $\mathrm{EU}$ as an entity with various 
decision-making levels and delivering policies based on principles of cooperation, solidarity and shared-sovereignty. When communicating proposals for EU reform in different national settings of EU member states, proponents of reforms should consider how the public in a given national setting makes sense of the EU and reform proposals should be tailored accordingly - possibly including messages catering to different thought communities.

Second, public diplomacy strategies and national branding campaigns should not be targeted at 'national' thought communities in foreign countries. As noted in the above, national contexts are characterized by constellations of thought communities and meanings - including those about other countries are constructed in these communities. Branding- and public diplomacy campaigns should hence be preceded targeting specific national contexts should hence be preceded by analyses of constellations of thought communities in that context.

In sum, the current article indicates that in ambiguous political orders such as the EU, it is useful to complement the study of public attitudes towards various policy aspects by the study of construals present among the citizens. RCA-based studies should then be enhanced by further analyses based on qualitative methods to deepen the robustness of the findings. Also, further study should be devoted to the question of how socio-demographic factors and degrees of europeanness of citizens in the EU may correlate with membership in thought communities.

Jozef Bátora is professor at the Department of Political Science, Faculty of Arts at Comenius University in Bratislava and at the IR Department, Webster Vienna Private University in Vienna. His research focuses on organizational and institututional change in EU governance, EU foreign policy and international security. Previously, he held scholarly posts at ARENA University of Oslo, Austrian Academy of Sciences and at Stanford University. He has published widely in peer reviewed journals including Journal of European Public Policy, Journal of Common Market Studies and West European Politics. His most recent book is Towards a Segmented European Political Order (with John E. Fossum, eds., Routledge 2020).

Pavol Baboš is a senior researcher at the Department of Political Science, Faculty of Arts, Comenius University in Bratislava. His main research area is Euroscepticism and voting behavior. He regularly publishes in international academic journals and contributes to popularization of science in Slovak media. He has rich experience in multinational European research consortia, in the past he taught methodology of political science in Comenius University in Bratislava and Bologna University, Italy. 


\section{REFERENCES}

ANSELL, C., 2000: The Networked Polity: Regional Development in Western Europe. Governance 13(2): 303-333. https://doi.org/10.1111/0952-1895.00136

BABOŠ, P. - VILÁGI, A., 2017: One Union, Two Universes? Critical Perception of the EU in Six EU Member States. Discussion Paper. (December 12, 2017). Available at SSRN: http://dx.doi.org/10.2139/ssrn.3086542

BALDASSARRI, D. - GOLDBERG, A., 2014: Neither Ideologues nor Agnostics: Alternative Voters' Belief System in an Age of Partisan Politics. American Journal of Sociology 120(1): 45-95. DOI: 10.2307/2669291

BARTOLINI, S., 2005: Restructuring Europe: Centre Formation, System Building, and Political Structuring Between the Nation State and the European Union. Oxford: Oxford University Press. DOI:10.1093/0199286434.001.0001

BÁTORA, J. - HYNEK, N., 2014: Fringe Players and the Diplomatic Order: The 'New' Heteronomy. Basingstoke: Palgrave. https://doi.org/10.1057/9781137383037_1

BÁTORA, J. - FOSSUM, J. E., 2020 (eds.): Towards a Segmented European Political Order: The European Union's Post-Crises Conundrum. London: Routledge. Available at SSRN: https://ssrn.com/abstract=3529331

BERGER, P. - LUCKMANN, Th., 1967: The Social Construction of Reality. New York: Penguin Press. ISBN: 9780140135480

BOOMGAARDEN, H. G. - SCHUCK, A. R. T. - ELENBAAS, M. - de VREESE, C. H., 2011: Mapping EU attitudes: Conceptual and empirical dimensions of Euroscepticism and EU support. European Union Politics 12(2): 241-266. https://doi.org/10.1177/1465116510395411

DAENEKINDT, S. - KOSTER, W. - van der WAAL, J., 2017: How People Organise Cultural Attitudes: Cultural Belief Systems and the Populist Radical Right. West European Politics 40(4): 791-811. https://doi.org/10.1080/01402382.2016.1271970

De VAUS, D., 2014: Surveys in Social Research (6th ed.). Routledge's Social Science Today Series. New York: Routledge. https://doi.org/10.4324/9780203519196

DELORS, J., 1985: Speech by Jacques Delors to the First intergovernmental conference in Luxemburg, Bulletin of the European Communities. September 1985, No 9. Luxembourg: Office for official publications of the European Communities.

DEUTSCH, K. W., 1957: Political Community in the North American Area: International Organization in the Light of Historical Experience. Princeton, NJ: Princeton University Press. ISBN: 9780691649429

DiMAGGIO, P. - GOLDBERG, A., 2018: Searching for Homo Economicus: Variation in Americans' Construals of and Attitudes toward Markets. European Journal of Sociology, online, pp. 1-39. DOI: https://doi.org/10.1017/S0003975617000558

MEDRANO, D. J., 2003: Framing Europe: Attitudes to European Integration in Germany, Spain, and the United Kingdom. Princeton, NJ: Princeton University Press. https://doi.org/10.1080/10848770.2012.699319

ESPING-ANDERSEN, G., 1990: The Three Worlds of Welfare Capitalism. Princeton, NJ: Princeton University Press. https://doi.org/10.1177/000169939203500106

FLIGSTEIN, N., 2008: Euroclash: The EU, European Identity and the Future of Europe. Oxford: Oxford University Press. DOI:10.1017/S0003975609000265 
FOSSUM, J. E., 2005: Conceptualizing the EU's Social Constituency. European Journal of Social Theory 8(2): 123-147. https://doi.org/10.1177/1368431005051760

FOSSUM, J. E. - GRAVER, H. P., 2018: Squaring the Circle on Brexit: Could the Norway Model Work? Bristol: Bristol University Press. ISBN 978-1529200300

GOLDBERG, A., 2011: Mapping Shared Understandings Using Relational Class Analysis: The Case of the Cultural Omnivore Reexamined. American Journal of Sociology 116(5): 1397-1436. DOI: 10.1086/657976

GOLDBERG, A. - STEIN, S. K., 2016: RCA: Relational Class Analysis. R-Package. Available online on 20 June 2018 at: https://cran.r-project.org/package=RCA

HAAS, E., 1964: Beyond the Nation State: Functionalism and International Organization. Stanford, CA: Stanford University Press. ISBN: 0804701873 978080470187708047018659780804701860

HIX, S., 2004: The study of the European community: The challenge to comparative politics. West European Politics 17(1): 1-30. https://doi.org/10.1080/01402389408424999

HOOGHE, L. - MARKS, G., 2005: Calculation, Community and Cues: Public Opinion on European Integration. European Union Politics 6(4): 419-443. https://doi.org/10.1177/1465116505057816

HOOGHE, L. - HUO, J. - MARKS, G., 2007: Does Occupation Shape Attitudes on Europe? Benchmarking Validity and Parsimony. Acta Politica 42: 329-351. DOI https://doi.org/10.1057/palgrave.ap.5500190

JESSOP, B., 2004: Multilevel Governance and Multilevel Metagovernance. Changes in the EU as Integral Moments in the Transformation and Reorientation of Contemporary Statehood. In: Bache, I. - Flinders, M. (eds.): Multi-Level Governance. Oxford: Oxford University Press, pp 49-74.

DOI:10.1093/0199259259.003.0004

KRASNER, S. D., 1999: Sovereignty: Organized Hypocrisy. Princeton, NJ: Princeton University Press. ISBN: 9780691007113

KUHN, Th., 2011: Individual Transnationalism, Globalisation and Euroscepticism: An Empirical Test of Deutsch's Transactionalist Theory. European Journal of Political Research 50(6): 811-837. https://doi.org/10.1111/j.1475-6765.2011.01987.x

KUHN, Th., 2012: Europa Ante Portas: Border Residence, Transnational Interaction and Euroscepticism in Germany and France. European Union Politics 13(1): 94117. https://doi.org/10.1177/1465116511418016

KUHN, Th., 2015: Experiencing European Integration: Transnational Lives and European Identity. Oxford: Oxford University Press. https://doi.org/10.1080/13501763.2019.1622588

LAVENEX, S., 2009: Switzerland's Flexible Integration in the EU: A Conceptual Framework. Swiss Political Science Review 15(4): 547-575. ttps://doi.org/10.1002/j.1662-6370.2009.tb00145.x

LAVENEX, S. - SCHIMMELFENNIG, F., 2009: EU Rules Beyond EU Borders: Theorizing External Governance in European Politics. Journal of European Public Policy 16(6): 791-812. https://doi.org/10.1080/13501760903087696 
LAVENEX, S. - SCHIMMELFENNIG, F., 2011: EU Democracy Promotion in the Neighbourhood: From Leverage to Governance? Democratization 18(4): 885-909. DOI: $10.1080 / 13510347.2011 .584730$

LOVELESS, M. - ROHRSCHNEIDER, R., 2011: Public Perceptions of the EU as a System of Governance. Living Reviews in European Governance 6(2): http://www.livingreviews.org/lreg-2011-2, accessed on Jan 29, 2019.

DOI: $10.12942 /$ lreg-2011-2

MORAVCSIK, A., 1998: The Choice for Europe. Ithaca, NY: Cornell University Press. DOI: https://doi.org/10.2307/2586098

MACRON, E., 2018: Discours du Président de la République au Parlement européen, April 17, 2018, available at http://www.elysee.fr/declarations/article/discours-dupresident-de-la-republique-au-parlement-europeen/, accessed on January 30, 2019.

MANNHEIM, K., 1954: Ideology and Utopia: An Introduction to the Sociology of Knowledge. New York: Harcourt, Brace \& Co. ISBN-10: 1614277729

MARCH, J. G. - OLSEN, J. P., 1989: Rediscovering Institutions: The Organizational Basis of Politics. New York: Free Press.

DOI: https://doi.org/10.1017/S0143814X00005869

McLAREN, L., 2002: Public Support for the European Union: Cost/Benefit Analysis or Perceived Cultural Threat? Journal of Politics 64: 551-566.

McLAREN, L., 2006: Identity, Interests, and Attitudes to European Integration. Basingstoke: Palgrave. ISBN-10 : 1349543748 ; ISBN-13 : 978-1349543748

MAU, S., 2007: Transnationale Vergesellschaftung. Die Entgrenzung sozialer Lebenswelten. Frankfurt: Campus Verlag.

MITRANY, D., 1943/1994: A Working Peace System. In: Nelsen, B. F. - Stubb, A. C. G. (eds), The European Union. London: Palgrave.

NORRIS, P., 1999: The Political Regime. In: Schmitt, H. - Thomassen, J. (eds.): Political Representation and Legitimacy in the European Union. Oxford: Oxford University Press, pp. 74-90. DOI:10.1093/0198296614.001.0001

OFFE, C., 2003: The European Model of „Social” Capitalism: Can it Survive European Integration? Journal of Political Philosophy 11(4): 437-469. DOI: 10.1046/j.14679760.2003.00185.x

OLSEN, J. P., 2010: Governing through Institution Building. Oxford: Oxford University Press. ISBN: 9780199593934

PARLEMETER, 2018: Taking up the Challenge: From (Silent) Support to Actual Vote. Eurobarometer survey commissioned by the European Parliament Directorate-General for Communication, Public Opinion Monitoring Unit, October 2018 - PE 628.262 (https://www.europarl.europa.eu/at-your-service/files/be-heard/euro barometer/2018/parlemeter-2018/report/en-parlemeter-2018.pdf, accessed on Feb 5, 2019)

POWELL, W. M., 1990: Neither Market nor Hierarchy; Network Forms of Organization. In: Staw, B. M. - Cummings, L. L. (eds.): Research in Organizational Behavior Vol. 12, pp. 295-336. Greenwich: CT: JAI Press.

PUCHALA, D., 1972: Of Blind Men, Elephants and International Integration. Journal of Common Market Studies 10(3): 267-284. https://doi.org/10.1111/j.14685965.1972.tb00903.x 
RUGGIE, J. G., 1993: Territoriality and Beyond: Problematizing Modernity in International Relations. International Organization 47(1): 139-174.

DOI: https://doi.org/10.1017/S0020818300004732

SCHARPF, F., 2002: The European Social Model: Coping with the Challenges of Diversity. MPIfG working paper, No. 02/8, Max-Planck-Institut für Gesellschaftsforschung, Köln: (http://www.mpifg.de/pu/workpap/wp02-8/wp02-8.html, accessed on January 25, 2019)

SCHUTZ, A., 1944: The Stranger: Essay in Social Psychology. American Journal of Sociology 49(6): 499-507. https://doi.org/10.1086/219472

Van OORSCHOT, W., 2006: Making the Difference in Social Europe: Deservingness Perceptions Among Citizens of European Welfare States. Journal of European Social Policy 16(1): 23-42. https://doi.org/10.1177/0958928706059829

WEICK, K. E., 1995: Sensemaking in Organizations. Thousand Oaks, CA: Sage. DOI: $10.1016 /$ S0956-5221(97)86666-3

WEICK, K. E., 2001: Making Sense of the Organization. Oxford: Blackwell. ISBN10 0631223193 ISBN13 9780631223191

ZERUBAVEL, E., 1997: Social Mindscapes: An Invitation to Cognitive Sociology. Cambridge, MA: Harvard University Press. ISBN 9780674813908 


\section{Appendix 1: Indicators Measuring Attributes of Political Order}

1. The EU should have a federal ministry of foreign affairs, an army, a border guard and a ministry of finance

2. We should govern our national affairs irrespective of EU institutions and other EU member states

3. The EU should have a directly elected President, who would compete in allEuropean election and lead the European Commission as government-style body.

4. Democratic politics should work on the EU level, for example in a form of a system of European political parties

5. The way democracy works is an exclusive matter of a national state and the EU should not intervene in the democratic set up and process in its member states.

6. The EU should promote democracy in the neighbouring countries, including financial support of the civic society abroad.

7. EU should continue pushing for lower taxes, more productivity and more competition in our country and in other EU member states

8. EU should expand its social welfare protection for all EU citizens to protect us from global market forces

9. EU should push for an absolute freedom of movement, including digital services and manualworkers

10. EU is bringing us peace and it should remain its main purpose

11. EU integration has gone too far and tensions it generates could lead to war in Europe

12. Breakdown of the EU would immensely increase the probability of new war in Europe

13. Political leaders of MY COUNTRY should decide upon important global issues independently and not wait for counsel/opinion of other European leaders.

14. MY COUNTRY should share secret intelligence and police information with other EU members extensively.

15. MY COUNTRY's government should take the interest of other EU members into account, even if it sometimes means concessions and compromises at our own costs.

Note: Respondents were shown the items and asked to indicate to what extent they agree, using the 5-point Likert scale. 
Appendix 2: Attitudes on Selected Issues within Individual Thought Communities

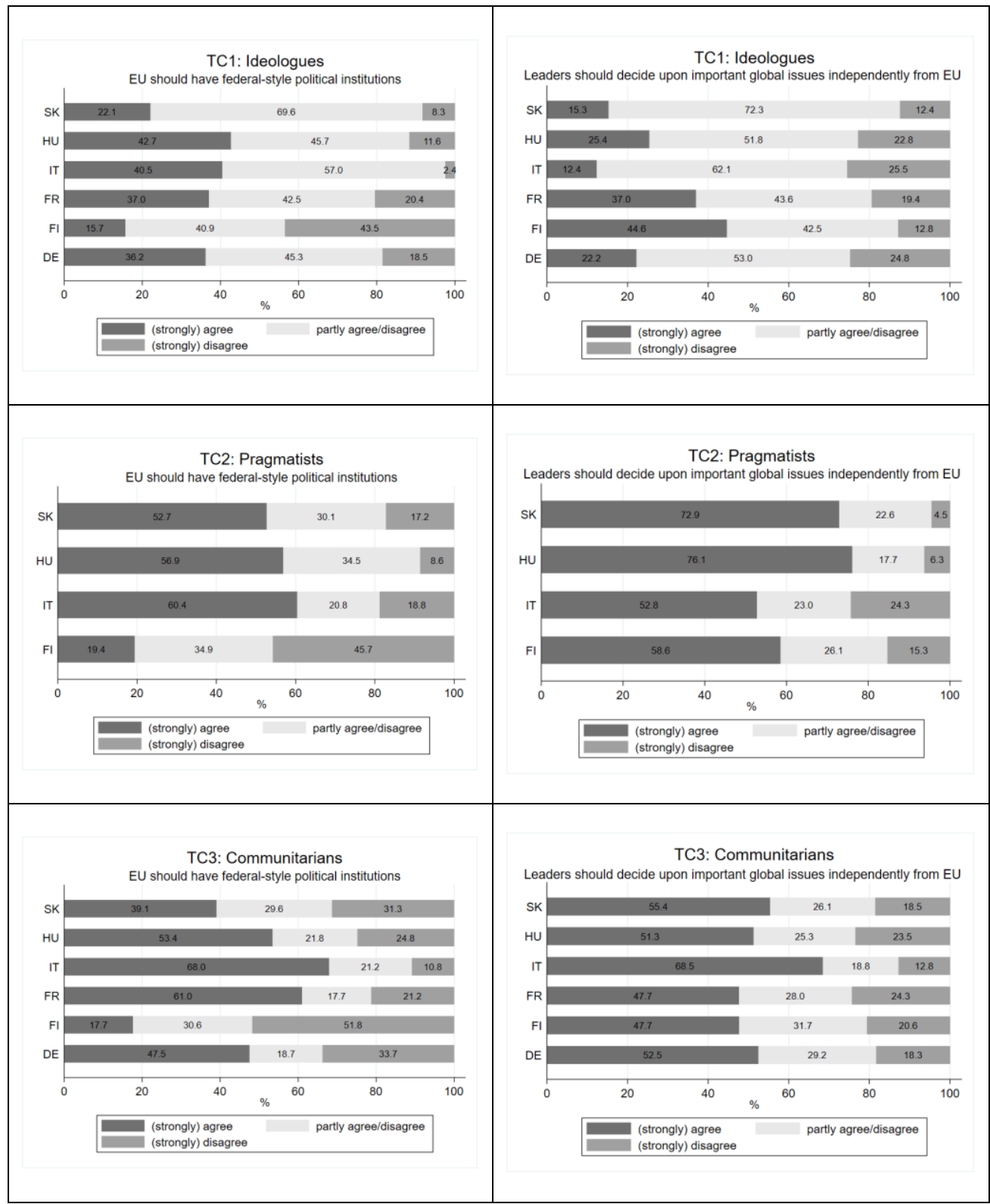

Source: Authors 
Appendix 3: Multinomial Logistic Regression Results

Table 4: Results of Multinomial Logistic Regression for Categories of Relational Class Membership

\begin{tabular}{|c|c|c|c|c|c|c|}
\hline & SK & HU & IT & FR & FI & DE \\
\hline \multicolumn{7}{|c|}{ BASE= TC1 / Ideologues } \\
\hline \multicolumn{7}{|l|}{ TC2 / Pragmatists } \\
\hline Age & 1.002 & 0.988 & 0.995 & & 0.986 & \\
\hline Income & 0.923 & 0.913 & $1.132 *$ & & 0.913 & \\
\hline \multicolumn{7}{|l|}{ Education (base=low) } \\
\hline Middle EDU & 0.443 & 1.359 & 0.917 & & 1.090 & \\
\hline Higher EDU & 0.362 & 1.158 & 0.854 & & 0.588 & \\
\hline Gender $(b=$ female $)$ & $1.813^{*}$ & 1.357 & 0.927 & & 0.901 & \\
\hline Residence & 1.109 & $1.248^{*}$ & 1.051 & & 1.052 & \\
\hline Travel intensity & 1.032 & 1.008 & 1.069 & & $0.743 *$ & \\
\hline Languages & 0.876 & 1.027 & 1.135 & & 0.926 & \\
\hline Lived abroad $(b=n o)$ & 0.785 & $2.565^{* * *}$ & 0.908 & & 0.812 & \\
\hline \multicolumn{7}{|c|}{ TC3 / Etatists/Traditionalists } \\
\hline Age & 0.999 & 0.990 & 1.017 & 0.991 & & $0.987 *$ \\
\hline Income & 0.994 & 1.014 & 1.076 & 0.944 & & 0.983 \\
\hline \multicolumn{7}{|l|}{ Education $($ base $=$ low $)$} \\
\hline Middle EDU & 0.456 & 1.557 & 1.336 & 0.934 & & 0.672 \\
\hline Higher EDU & 0.416 & 0.913 & 1.527 & 0.789 & & $0.451 * *$ \\
\hline Gender $(b=$ female $)$ & $1.730^{*}$ & 0.921 & 0.706 & 1.095 & & 1.193 \\
\hline Residence & 0.944 & $1.241 *$ & 1.109 & 0.856 & & 1.006 \\
\hline Travel intensity & 0.959 & 1.036 & 0.851 & 0.919 & & 0.979 \\
\hline Languages & 1.163 & 1.168 & $0.637^{*}$ & 0.932 & & 1.025 \\
\hline Lived abroad $(b=$ no $)$ & 0.907 & 0.938 & 0.626 & 1.203 & & 0.730 \\
\hline \multicolumn{7}{|c|}{ Special TC Finland / No System Thinking } \\
\hline Age & & & & & 0.988 & \\
\hline Income & & & & & 1.126 & \\
\hline Education $($ base $=$ low $)$ & & & & & 1.000 & \\
\hline Middle EDU & & & & & 0.747 & \\
\hline Higher EDU & & & & & 0.613 & \\
\hline Gender $(b=$ female $)$ & & & & & 1.087 & \\
\hline Residence & & & & & 0.837 & \\
\hline Travel intensity & & & & & 0.957 & \\
\hline Lived abroad $(b=$ no $)$ & & & & & 1.122 & \\
\hline
\end{tabular}

Source: Authors

Note: *-p-value $<0.05$

$* *$ - p-value $<0.01$

$* * *$ - p-value $<0.001$

Note 2: Coefficients are presented in a form of relative risk ratios. Constant not shown. 
Appendix 4: Network Diagrams for Thought Communities

Country $\mathrm{TC} 1 /$ Ideologues


HU

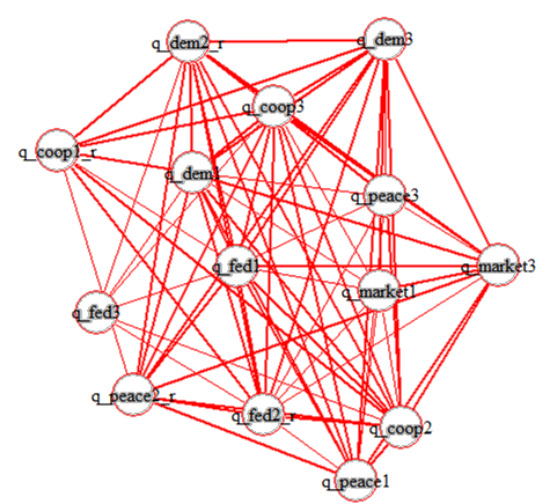

IT

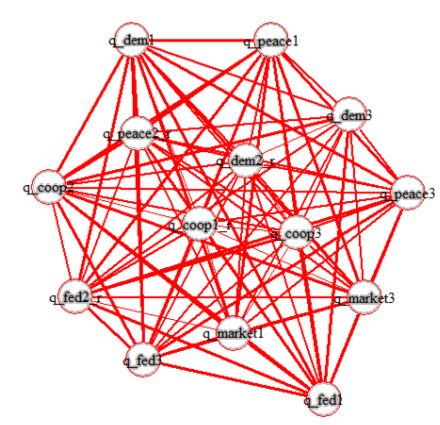

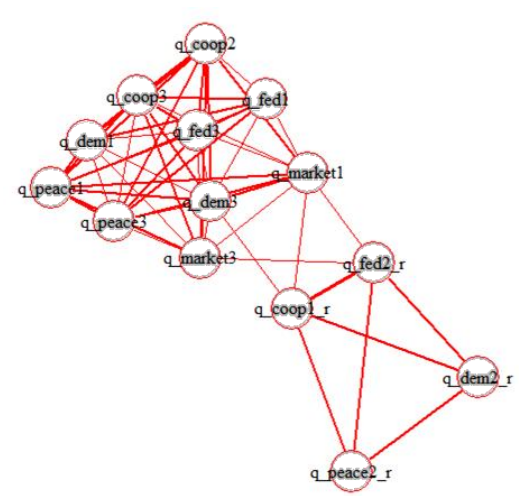

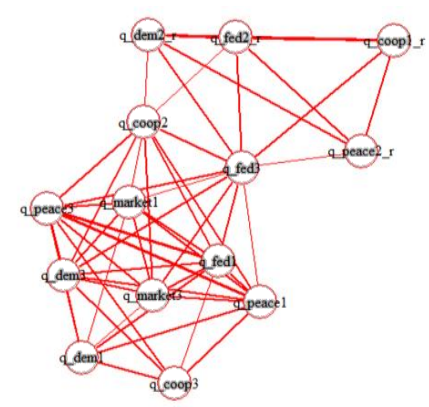

(ject)

2(20)

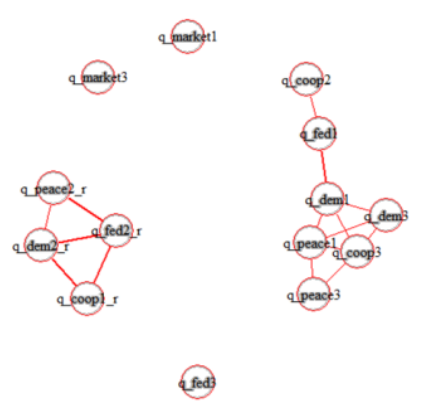


FR

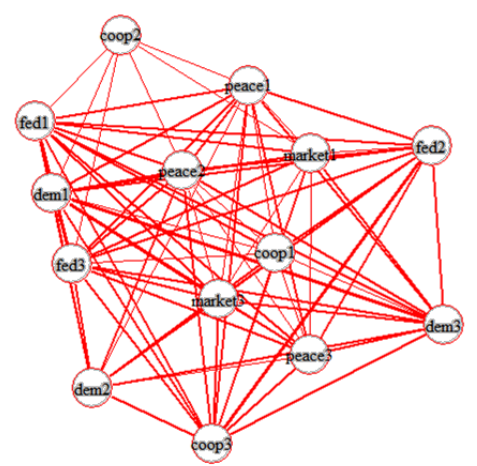

DE

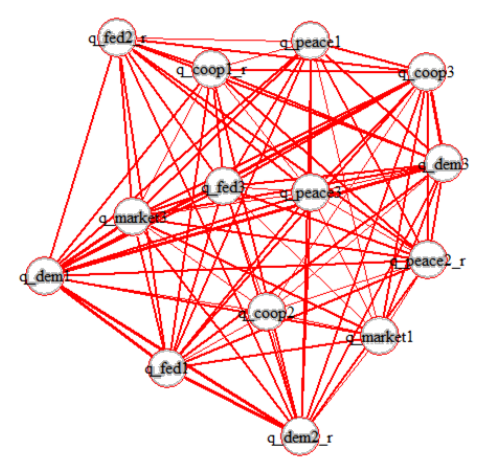

(60p)

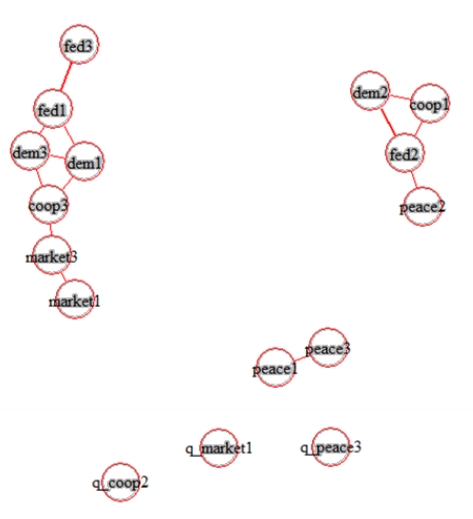

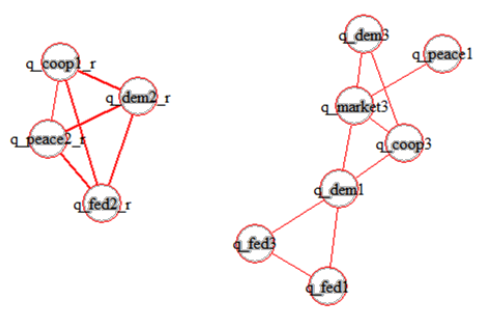

